\title{
EDITORIAL
}

\section{Syncope in Malaysian populations}

\author{
Robert S. Sheldon ${ }^{1}$
}

Received: 24 December 2019 / Accepted: 25 December 2019 / Published online: 10 January 2020

(c) Springer-Verlag GmbH Germany, part of Springer Nature 2020

Many people faint. Syncope poses a significant burden to the patient, with a risk of injuries and a reduction in quality of life [1, 2]. It also poses a burden to health care systems, causing 1-2\% of emergency department admissions, fruitlessly high admission rates to hospital, and high costs of investigations [3]. Despite this, there are relatively few studies that document syncope impact and numbers at a population level, and even fewer that explore ethnic differences. In this issue of Clinical Autonomic Research, Tan and colleagues [4] provide a beautiful contribution to the field. They reported ethnic differences in lifetime cumulative incidence of syncope in Malaysia, and found large differences in both yearly and lifetime cumulative incidence in the three major Malaysian populations: the ethnic Chinese, ethnic Indian (mainly south Indian Tamils), and the ethnic Malays. The estimates of yearly incidence and lifetime cumulative incidence compare well with both Dutch [5] and Canadian [6] studies, both of which comprise people with predominantly European heritage.

Interestingly, Tan and colleagues [4] reported considerably less syncope in the Chinese population than in Tamils and Malays. What might be the cause of these differences? One possibility is simply how the syncope data were collected. Although the study was thoughtfully designed and conducted, with granular data collected with ethnically and linguistically appropriate face-to-face interviews and highly structured case report forms, patients will admit to syncope only if they understand the term. The authors considered this, but local culture and language might still lead to under-reporting. Even in England there are large regional differences in the uses of the terms black-out, faint, fit, funny turn, funny spell, and collapse. Similarly, patients may need prompting more than once to admit to a distant

Robert S. Sheldon

sheldon@ucalgary.ca

1 Department of Cardiac Sciences, Libin Cardiovascular Institute of Alberta, Cumming School of Medicine, GAA02, HRIC Building, University of Calgary, 3280 Hospital Drive NW, Calgary, AB T2N 4Z6, Canada history of syncope. In our clinic, this is more the rule than the exception, and in Tan et al. [4], this might have led to under-reporting.

A third and possibility is socioeconomic status, which for over 200 years has been known to correlate with symptoms, disease, and outcome. The Whitehall study [7] is a particularly striking example, in which UK civil servants in the higher administrative levels had better outcomes than those in even slightly lower levels. Chinese Malaysians tend to be wealthier than Indian Malaysians and Malays, and their Table 2 documents higher educational achievements as well. Fully $82 \%$ of Chinese Malaysians had at least secondary educations, compared to $78 \%$ and $55 \%$ of Indian Malaysians and Malays, respectively [4].

Might there also be biological causes? Most fundamentally, does vasovagal syncope have genetic causes? There are phenotypic and genetic reasons to think this might be true [8]. Vasovagal syncope seems to cluster in some families, recurs throughout the life of fainters, occurs in only some people, and the clinical phenotype stability is mirrored by the general reproducibility of tilt test results. Twin studies and small genome-wide association studies hint at genetic loci [8]. Candidate gene studies have identified adrenergic signalling pathways that correlate with tilt test outcomes, and a study [9] of seven kindreds identified three candidate genes associated with serotonin and dopamine signalling. Studies of vasovagal syncope, however, have focused on European heritage populations, either in Europe [10-13] or the Americas [6, 9, 14-16].

If modern humans have genetic correlates with syncope, then when did modern humans begin to faint? Haplotype analysis can help. Mothers pass on mitochondrial DNA (mtDNA), and fathers pass on Y chromosomal DNA (Y DNA). Both DNAs mutate with time at documented rates and with documented lineages, and the evolution of mtDNA and $\mathrm{Y}$ chromosome haplotypes permits us to track the movement of ancestral human populations as they moved from Africa to the rest of the world. Almost all inferences are statistical and the changes in concepts over the years reflect both new findings and the difficulties in 
sorting out complex population sizes and migrations over the millennia. Given that most of the inferences are statistical and based on modern haplotype distributions, it is not surprising that there is debate about many conclusions.

Nonetheless, the Recent Out Of Africa model [17-19] posits that all modern human groups now out of Africa derived from a small population of mtDNA L3 people, either shortly before or shortly after they crossed from the Horn of Africa to the Arabian peninsula around 70,000 years ago. They then migrated along the coasts of India and south Asia to Australia, leaving small populations along the way [18]. These became the M peoples. At some early point the $\mathrm{N}$ people either arose from the $\mathrm{L} 3$ people or the $\mathrm{M}$ peoples and may have crossed northern India or central Asian steppes, continuing on to central China. Some of their descendants became the $\mathrm{N}$ peoples. Modern Tamils are mostly from M people, modern Han Chinese are mostly $\mathrm{N}$ people, and the modern Malays seem to have arisen predominantly from a direct southern migration of $\mathrm{N}$ peoples from archaic China 10-30,000 years ago, with a smaller second flow from Taiwan 5000-7000 years ago [20].

Taken together, the Tamil, Han, and Malay populations may have diverged from each other and from the European $\mathrm{N}$ peoples as early as $50-70,000$ years ago, implying that humans began fainting before some left Africa. Despite this, the populations have a roughly similar cumulative lifetime incidence of syncope of $25-40 \%$, a remarkably stable proportion for a trait with a survival benefit that does not quickly come to mind. Syncope in these ancient and genetically distinct populations raises several interesting questions. Do fainting Malaysian parents of different backgrounds confer the same risk of syncope to their children as reported for Canadian parents of predominantly European heritage? [6] Are the same candidate genes associated with positive tilt tests in the different Malaysian populations as those from Polish [11-13] and Mexican [14-16] populations? If so, then vasovagal syncope has its roots deep in the history of modern humans. Finally, are the same alleles associated with clinical vasovagal syncope in all the Malaysian populations as in European-Canadians? This is critical, because these three genes-the serotonin transporter, the serotonin $1 \mathrm{~A}$ receptor, and catecholamine O-methyltransferase-have different effects on syncope likelihood in men and women [9]. Tan et al. [4] carefully documented the incidence of syncope in several populations many thousands of years apart, and in doing so lay the groundwork for fundamentally important work in the future.

Funding None.

\section{Compliance with ethical standard}

Conflict of interest The authors declare that they have no conflict of interest.

\section{References}

1. Ng J, Sheldon RS, Maxey C, Ritchie D, Raj V, Exner DV, Raj SR (2019) Quality of life improves in vasovagal syncope patients after clinical trial enrollment regardless of fainting in follow-up. Auton Neurosci 219:42-48

2. Ng J, Sheldon RS, Ritchie D, Raj V, Raj SR (2019) Reduced quality of life and greater psychological distress in vasovagal syncope patients compared to healthy individuals. Pacing Clin Electrophysiol 42(2):180-188

3. Shen WK, Sheldon RS, Benditt DG, Cohen MI, Forman DE, Goldberger ZD, Grubb BP, Hamdan MH, Krahn AD, Link MS, Olshansky B, Raj SR, Sandhu RK, Sorajja D, Sun BC, Yancy CW (2017) 2017 ACC/AHA/HRS Guideline for the Evaluation and Management of Patients With Syncope: executive summary: a report of the American College of Cardiology/American Heart Association Task Force on clinical practice guidelines and the heart rhythm society. J Am Coll Cardiol 70:620-663

4. Tan MP, Ho YY, Chin AV, Saedon N, Abidin IZ, Chee KH, Khor HM, Goh CH, Hairi NN, Othman S, Kamaruzzaman SB (2019) Ethnic differences in lifetime cumulative incidence of syncope: the Malaysian elders longitudinal research (MELoR) study. Clin Auton Res. https://doi.org/10.1007/s10286-019-00610-2

5. Ganzeboom KS, Mairuhu G, Reitsma JB, Linzer M, Wieling W, van Dijk N (2006) Lifetime cumulative incidence of syncope in the general population: a study of 549 Dutch subjects aged 35-60 years. J Cardiovasc Electrophysiol 17:1172-1176

6. Serletis A, Rose S, Sheldon AG, Sheldon RS (2006) Vasovagal syncope in medical students and their first-degree relatives. Eur Heart J 27:1965-1970

7. Marmot MG, Smith GD, Stansfield S, Patel C, North F, Head J, White I, Brunner E, Feeney A (1991) Health inequalities among British civil servants: the Whitehall II study. Lancet 337:1387-1393

8. Sheldon RS, Sandhu RK (2019) The search for the genes of vasovagal syncope. Front Cardiovasc Med 6:175

9. Sheldon R, Rose MS, Ritchie D, Martens K, Maxey C, Jagers J, Parboosingh J, Gerull B (2019) Genetic association study in multigenerational kindreds with vasovagal syncope. Circ Arrhythm Electrophysiol 12:e06884

10. Klein KM, Bromhead CJ, Smith KR, O'Callaghan CJ, Corcoran SJ, Heron SE, Iona X, Hodgson BL, McMahon JM, Lawrence KM, Scheffer IE, Dibbens LM, Bahlo M, Berkovic SF (2013) Autosomal dominant vasovagal syncope: clinical features and linkage to chromosome 15q26. Neurology 80:1485-1493

11. Zelazowska M, Lelonek M, Fendler W, Pietrucha T (2014) Arg389Gly $\beta 1$-adrenergic receptor polymorphism and susceptibility to syncope during tilt test. Arch Med Sci 10:240-245

12. Lelonek M, Pietrucha T, Matyjaszczyk M, Goch JH (2009) Polymorphism $\mathrm{C} 1114 \mathrm{G}$ of gene encoding the cardiac regulator of G-protein signaling 2 may be associated with number of episodes of neurally mediated syncope. Arch Med Res 40:191-195

13. Lelonek M, Pietrucha T, Matyjaszczyk M, Goch JH (2009) Genetic insight into syncopal tilted population with severe clinical presentation. Auton Neurosci 147:97-100

14. Hernandez-Pacheco G, Gonzalez-Hermosillo A, Murata C, Yescas P, Espinola-Zavaleta N, Martinez M, Serrano H (2014) Arg347Cys polymorphism of alpha1a-adrenergic receptor in 
vasovagal syncope. Case-control study in a Mexican population. Auton Neurosci 183:66-71

15. Márquez MF, Hernández-Pacheco G, Hermosillo AG, Gómez JR, Cárdenas M, Vargas-Alarcón G (2007) The Arg389Gly beta1adrenergic receptor gene polymorphism and susceptibility to faint during head-up tilt test. Europace 9:585-588

16. Marquez MF, Urias KI, Hermosillo AG, Jardon JL, Iturralde P, Colin L, Nava S, Cardenas M (2005) Familial vasovagal syncope. Europace 7:472-474

17. Liu H, Prugnolle F, Manica A, Balloux F (2006) A geographically explicit genetic model of worldwide human-settlement history. Am J Human Gen 79:230-237

18. Macaulay V, Hill C, Achilli A, Rengo C, Clarke D, Meehan W, Blackburn J, Semino O, Scozzari R, Cruciani F, Taha A, Shaari
NK, Raja JM, Ismail P, Zainuddin Z, Goodwin W, Bulbeck D, Bandelt HJ, Oppenheimer S, Torroni A, Richards M (2005) Single, rapid coastal settlement of Asia revealed by analysis of complete mitochondrial genomes. Science 308:1034-1036

19. Jh R (2008) Genetic evidence and the modern human origins debate. Heredity 100:555-563

20. Jinam TA, Hong L-C, Phipps ME, Stoneking M, Ameen M, Edo J, Saitou N, HUGO P-ASNPC (2012) Evolutionary history of continental southeast Asians: "Early Train" hypothesis based on genetic analysis of mitochondrial and autosomal DNA data. Mol Biol Evol 29:3513-3527 